\title{
Spring Migratory Pathways and Migration Chronology of Canada Geese (Branta canadensis interior) Wintering at the Santee National Wildlife Refuge, South Carolina
}

\author{
Molly M. Giles ${ }^{1}$, Patrick G. R. Jodice ${ }^{2,3}$, Robert F. Baldwin ${ }^{4}$, John D. Stanton ${ }^{5}$, and MarC \\ EPSTEIN $^{6}$
}

${ }^{1}$ School of Agriculture, Forest, and Environmental Science, Clemson University, Clemson, South Carolina 29634 USA; current address: Pennsylvania Game Commission, Northeast Region, 3917 Memorial Highway, Dallas, Pennsylvania 18612 USA; email: mgiles@pa.gov

${ }^{2}$ U.S. Geological Survey, South Carolina Cooperative Fish and Wildlife Research Unit, G27 Lehotsky Hall, Clemson University, Clemson, South Carolina 29634 USA

${ }^{3}$ Corresponding author; email: pjodice@clemson.edu

${ }^{4}$ School of Agriculture, Forest, and Environmental Science, Clemson University, Clemson, South Carolina 29634 USA; email: baldwi6@clemson.edu

${ }^{5}$ U.S. Fish and Wildlife Service, Migratory Bird Field Office, 185 L.A. Keiser Drive, Suite A, Columbia, North Carolina 27925 USA; email: john_stanton@fws.gov

${ }^{6}$ U.S. Fish and Wildlife Service, Santee National Wildlife Refuge, 2125 Fort Watson Road, Summerton, South Carolina 29148 USA; email: marc_epstein@fws.gov

Giles, Molly M., Patrick G. R. Jodice, Robert F. Baldwin, John D. Stanton, and Marc Epstein. 2013. Spring migratory pathways and migration chronology of Canada Geese (Branta canadensis interior) wintering at the Santee National Wildlife Refuge, South Carolina. Canadian Field-Naturalist 127(1): 17-25.

We assessed the migratory pathways, migration chronology, and breeding ground affiliation of Canada Geese (Branta canadensis interior) that winter in and adjacent to the Santee National Wildlife Refuge in Summerton, South Carolina, United States. Satellite transmitters were fitted to eight Canada Geese at Santee National Wildlife Refuge during the winter of 2009-2010. Canada Geese departed Santee National Wildlife Refuge between 5 and 7 March 2010. Six Canada Geese followed a route that included stopovers in northeastern North Carolina and western New York, with three of those birds completing spring migration to breeding grounds associated with the Atlantic Population (AP). The mean distance between stopover sites along this route was $417 \mathrm{~km}$, the mean total migration distance was $2838 \mathrm{~km}$, and the Canada Geese arrived on AP breeding grounds on the eastern shore of Hudson Bay between 20 and 24 May 2010. Two Canada Geese followed a different route from that described above, with stopovers in northeastern Ohio, prior to arriving on the breeding grounds on 9 June 2010. Mean distance between stopover sites was 402 and $365 \mathrm{~km}$ for these two birds, and total migration distance was 4020 and $3650 \mathrm{~km}$. These data represent the first efforts to track migratory Canada geese from the southernmost extent of their current wintering range in the Atlantic Flyway. We did not track any Canada Geese to breeding grounds associated with the Southern James Bay Population. Caution should be used in the interpretation of this finding, however, because of the small sample size. We demonstrated that migratory Canada Geese wintering in South Carolina use at least two migratory pathways and that an affiliation with the Atlantic Population breeding ground exists.

Key Words: migration, Canada Geese, Branta canadensis interior, satellite telemetry, Atlantic Population, Southern James Bay Population, staging areas, stopover sites, Atlantic Flyway, wintering ecology, South Carolina, Quebec, Ontario.

In North America, Canada Goose (Branta canadensis) populations are defined and partially managed based on affiliations with breeding grounds. Three populations of migratory Canada Geese occur in the Atlantic Flyway: the Atlantic Population, the North Atlantic Population, and the Southern James Bay Population (Hindman et al. 2004). Canada Geese from the Atlantic Population (predominantly Branta canadensis interior) nest north of $48^{\circ}$ north latitude in Quebec along the northeastern shore of Hudson Bay and the interior of the Ungava Peninsula (Davies and Hindman 2008*). These Canada Geese winter from southern Ontario eastward through the southernmost part of Quebec and southward to South Carolina, with concentrations on the Delmarva Peninsula and in portions of New York, southeastern Pennsylvania, New Jersey, and Virginia (Davies and Hindman 2008*).
Canada Geese from the North Atlantic Population (predominantly B. c. canadensis) breed in Labrador, the interior of Newfoundland, and eastern Quebec, and they winter along the Atlantic coastal zone from Labrador to South Carolina (Hindman et al. 2004). Canada Geese from the Southern James Bay Population (predominantly B. c. interior) breed along the southwestern shore of James Bay in Ontario and on Akimiski Island in Nunavut (Hindman et al. 2004; Abraham et al. 2008*). These Canada Geese winter in both the Atlantic and Mississippi flyways and are managed jointly by each flyway council (Hindman et al. 2004). In the Atlantic Flyway, these Canada Geese migrate through western Pennsylvania and winter in the Piedmont regions of North and South Carolina (Hindman et al. 2004). Both the breeding and the nonbreeding ranges and habitats are typically well defined and documented for each population. 
Over the past several decades, the wintering distribution of Canada Geese throughout eastern North America has shifted northward. Factors such as climate change, climate severity during winter, changes in farming and land-use practices, interactions with temperate-nesting Canada Geese (B. c. maxima, Giant Canada Geese), and the differential survival of southern-wintering cohorts are suspected to have contributed to the northern shift in winter distribution (Abraham et al. 2008*; Davies and Hindman 2008*).

In the Atlantic Flyway, this northern shift of migratory Canada Geese is evident in many southeastern states, where the abundance of wintering birds appears to be decreasing. Although numbers of migrant Canada Geese are low on southern wintering grounds, those Canada Geese that do return to wintering grounds in southern states appear to exhibit strong site fidelity to public lands, notably national wildlife refuges (Bellrose 1980; Orr et al. 1998; Combs et al. 2001).

Such is the case in South Carolina, where the number of migrant Canada Geese has been dwindling since the 1960s. Those birds that do return have an affinity for public lands, such as the Santee National Wildlife Refuge. Counts of migrant Canada Geese at the Santee National Wildlife Refuge peaked in the 1960s at approximately 40000 birds; currently, only 500 to 1000 Canada Geese appear to winter in and adjacent to the refuge (U.S. Fish and Wildlife Service 2008).

Canada Geese from the North Atlantic Population and the Southern James Bay Population have historically been associated with national wildlife refuges in South Carolina (Hindman et al. 2004; Davies and Hindman 2008*). Additionally, re-sighting of neckcollared Canada Geese during winter in the 1980s demonstrated an affiliation between Canada Geese from both the Atlantic Population and the Southern James Bay Population and wintering grounds in South Carolina (Malecki and Trost 1986). Despite recent changes in the distribution and abundance of Canada Geese in the Atlantic flyway, examinations of breeding and wintering ground affiliations for birds wintering in the southernmost extent of the range have been assessed only through banding data. Therefore, our objectives were to use satellite transmitters to determine migratory pathways, migratory chronology, and breeding ground affiliation of Canada Geese that winter at the southernmost extent of the migratory range, in Santee National Wildlife Refuge, South Carolina.

\section{Methods}

Canada Geese were captured on the Santee National Wildlife Refuge (Figure 1) located along Lake Marion, a reservoir of 44758 ha created by the South Carolina Public Service Authority between 1939 and 1942. The Santee National Wildlife Refuge is the most significant inland area for migratory waterfowl in South Carolina (U.S. Fish and Wildlife Service 2008), and it is managed in part to support Canada Geese from the Southern James Bay Population in the southeastern
Atlantic states. Migrant Canada Geese winter at the Santee National Wildlife Refuge from late November until early March.

Canada Geese ( $n=22$ females and 6 males) were captured on the Bluff Unit of the Santee National Wildlife Refuge during December of 2009 using rocket nets stationed in agricultural fields. Because the Santee National Wildlife Refuge was primarily interested in determining wintering habitat use by migrant Canada Geese in and adjacent to the Refuge, all satellite fitting needed to be completed as early in the winter season as possible (i.e., preferably prior to the end of December). Measurements of body mass (to the nearest $100 \mathrm{~g}$ ), culmen length (to the nearest $0.01 \mathrm{~mm}$ ), tarsus length (to the nearest $0.01 \mathrm{~mm}$ ), and wing chord (to the nearest $5 \mathrm{~mm}$ ) were recorded for all captured Canada Geese. We used broad ranges of body mass to distinguish subspecies following the ranges in body mass provided in Bellrose (1980).

After-hatch-year males and females deemed to be migratory B. c. interior (from either the Southern James Bay Population or the Atlantic Population) or $B$. $c$. canadensis (from the North Atlantic Population) were fitted with satellite (PTT) transmitters (either 45 gram, Microwave Telemetry Inc., Columbia, Maryland, U.S., or 60 gram TAV-2456 Telonics Inc., Mesa, Arizona). Transmitters were attached dorsally between the wings using a harness made of Teflon ribbon (Bally Ribbon Mills, Bally, Pennsylvania.). Transmitters were programmed on a three-day duty cycle through 30 April 2010 and a 10-day duty cycle thereafter. Canada Geese with transmitters were fitted with a federal U.S. Geological Survey aluminum leg band and a green leg band with a white alphanumeric code. All trapping and handling procedures were approved by the Clemson University Institutional Animal Care and Use Committee and the U.S. Geological Survey.

Satellite locations were obtained using the Argos data collection system (Argos 2008*). We choose one location per bird per day to use in subsequent analyses, based on criteria outlined in Miller et al. (2005) and Haukos et al. (2006). Location classes 3 (estimated error of $<150 \mathrm{~m}$ ), 2 (estimated error of 150 to $350 \mathrm{~m}$ ), and 1 (estimated error of 350 to $1000 \mathrm{~m}$ ) were favored. We used Hawth's Tools (Beyer 2004*) for ArcGIS 9.3 to determine migratory pathways and to calculate the total migration distance, as well as distances between stopover sites from the date of departure from the Santee National Wildlife Refuge until birds arrived on the breeding grounds.

North American land cover data (Commission for Environmental Cooperation 2010) were used to identify the primary land cover types in the landscapes surrounding each stopover or staging area used during spring migration. A $10-\mathrm{km}$ buffer was placed around each stopover or staging area, and the percentage of each land cover type within the buffered area was determined. We chose a $10-\mathrm{km}$ buffer because the range of all relocations at individual stopover sites was usually 


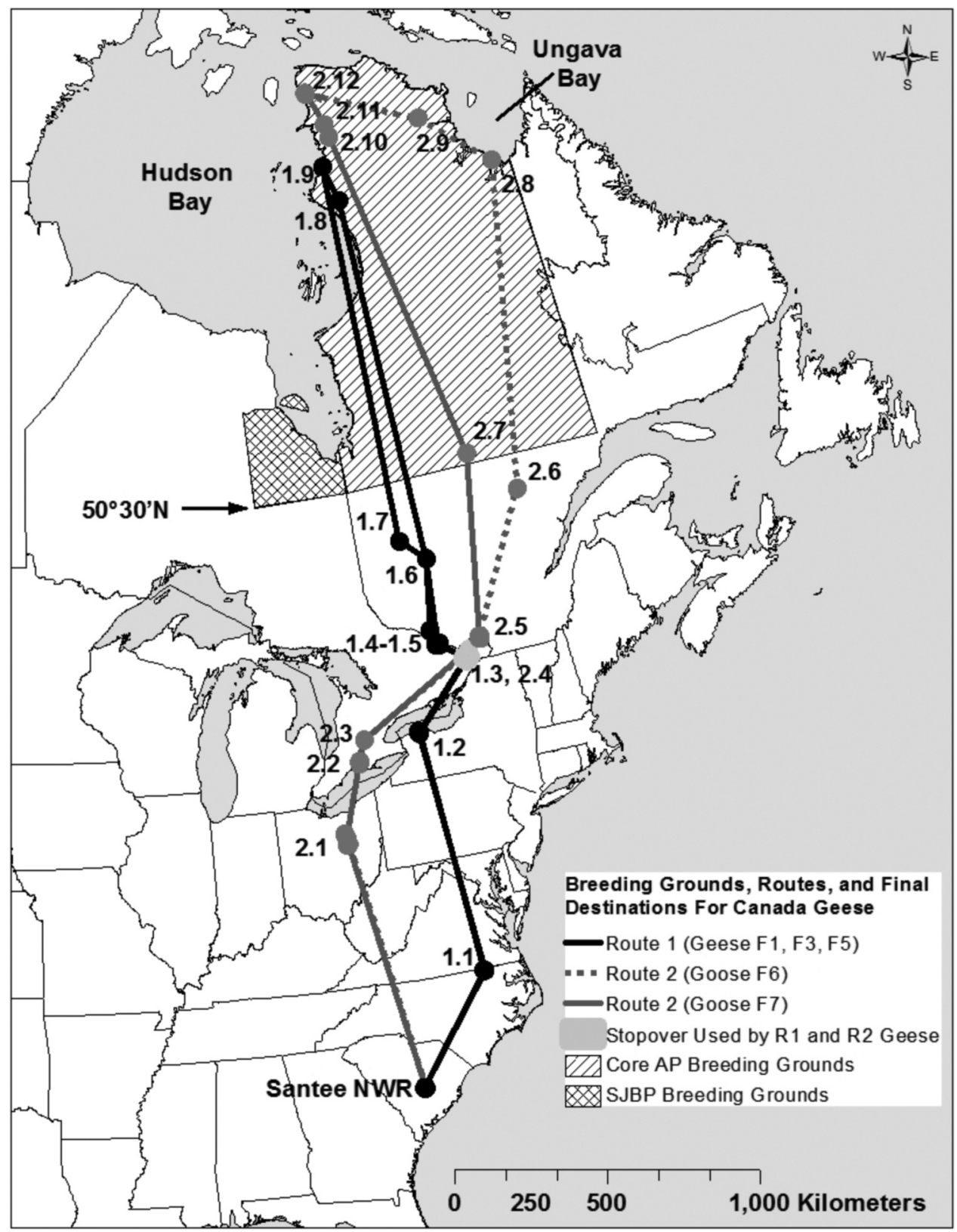

FIGURE 1. Migratory pathways used by Canada Geese (Branta canadensis interior) fitted with satellite transmitters during spring migration from wintering grounds at the Santee National Wildlife Refuge in South Carolina, 5 March 2010, to arrival on breeding grounds. Abbreviations (e.g., F1) refer to bird IDs listed in Table 1. Numbered locations (e.g., $1.1,1.2)$ represent sequential stopover sites on Route 1 or Route 2 (defined in Table 2). Satellite tags were programmed on a three-day duty cycle through 30 April and a 10-day duty cycle thereafter; lines are therefore interpretations to link points and do not reflect known flight paths. Note that Route 2 (Female 6) and Route 2 (Female 7) overlap from Santee National Wildlife Refuge through points 2.1 to 2.4. AP refers to Atlantic Population and SJBP refers to Southern James Bay Population. 
contained within this radius and because previous studies of wintering and migrating Canada Geese found that most daily movements during the stopover period were within a $10-\mathrm{km}$ radius (Reed et al. 1977).

\section{Results}

We trapped for a total of 143 hours over 24 days during December 2009 on the Bluff Unit of the Santee National Wildlife Refuge. Canada Geese were captured on just 2 of the 24 trapping days, thus limiting our choice in selecting individuals for satellite tracking (i.e., we were not able to restrict tagging to one bird per capture event, as planned). Six Canada Geese were captured together on 15 December 2009 and each was fitted with a satellite transmitter. Two of these birds, Male 1 and Female 2, were already banded at the time of capture. The band return information we later received indicated the banding site was within the breeding range of the Atlantic Population. Five Canada Geese were captured on 18 December 2009 and two were fitted with satellite transmitters (Table 1).

The Canada Geese fitted with satellite transmitters departed Santee National Wildlife Refuge between 5 and 7 March 2010. We selected 164 locations, postfiltering, between the date of departure and either the date of last transmission or the date of arrival on the breeding grounds (Table 1). Of the eight transmitters deployed, three ceased transmission during spring migration before the birds arrived at the breeding grounds. The cause of transmitter failure remains undetermined. The remaining five Canada Geese completed the spring migration to breeding grounds associated with the Atlantic Population on the Ungava Peninsula in Quebec.

Six Canada Geese followed a route with stopovers in northeastern North Carolina (stopover 1.1) and western New York (stopover 1.2) (hereafter Route 1) (Table 2 and Figure 1). Three of these transmitters (on Male 1 and Females 2 and 4) failed in late April. The last known locations were in southeastern Ontario. Females 1,3 , and 5 completed the spring migration to the eastern shores of Hudson Bay within the breeding grounds of the Atlantic Population (Figure 1). Along Route 1, the longest stopovers occurred in southeastern Ontario and southern Quebec (stopovers 1.4 and 1.5) (Table 2), with Canada Geese remaining in these areas from ca. 19 March to 1 April 2010 and from 3 April to 2 May 2010. Mean distance between stopovers for Females 1,3 , and 5 was $417 \mathrm{~km}$ (SE 76), and mean total migratory distance was $2838 \mathrm{~km}$ (SE 346) (Table 3). Canada Geese arrived on the breeding grounds ca. 24 May 2010.

Females 6 and 7 followed a route with stopovers in northeastern Ohio (stopover 2.1), southwestern Ontario (stopovers 2.2 and 2.3), southeastern Ontario (stopover 2.4), and southern Quebec (stopover 2.5) prior to arrival on the breeding grounds of the Atlantic Population (hereafter Route 2) (Table 2 and Figure 1). The longest stopovers along Route 2 also occurred in southeastern

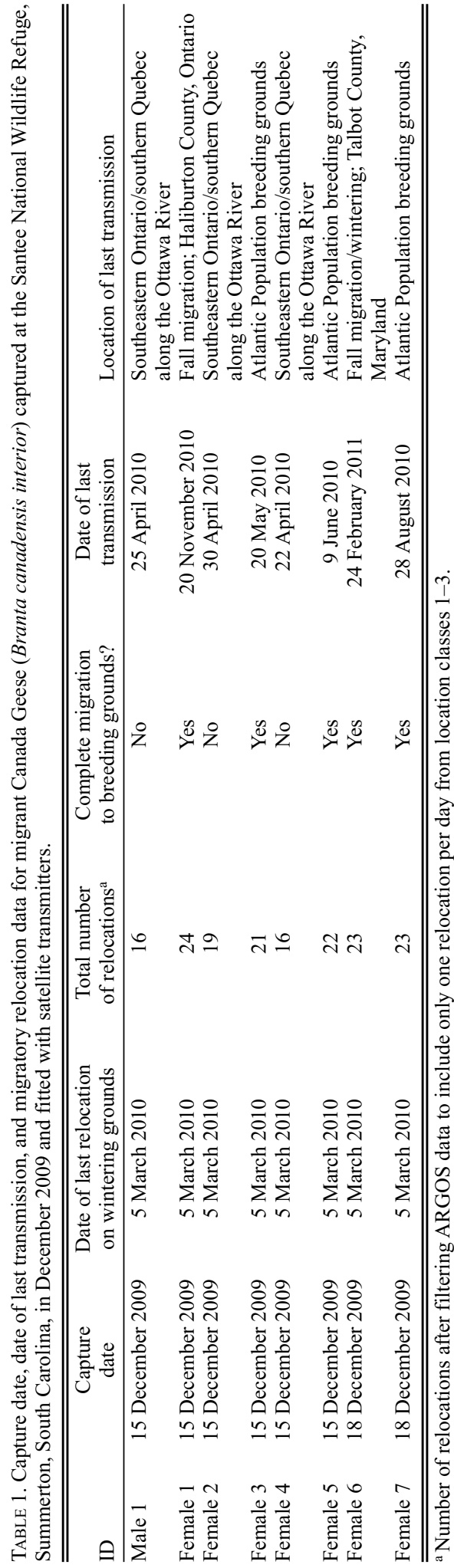




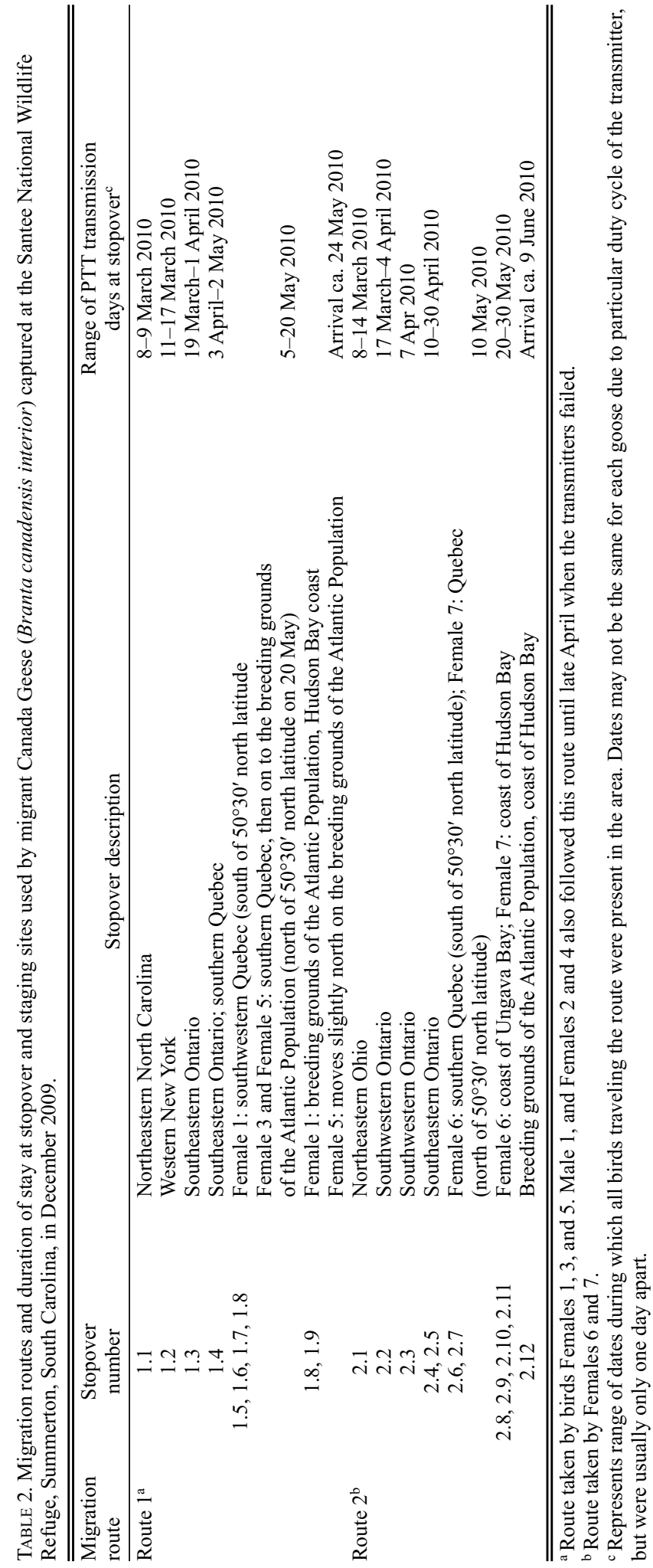




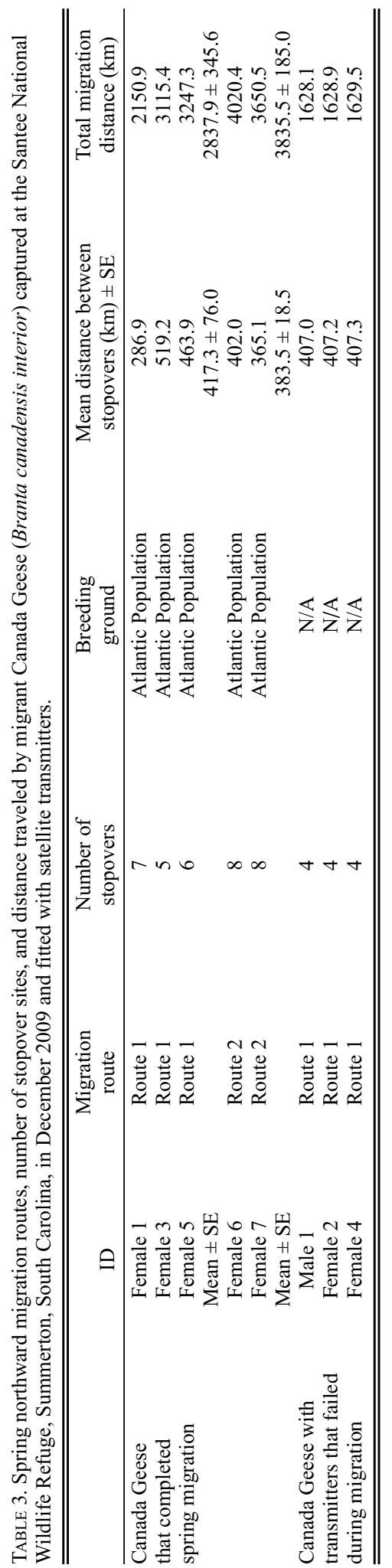

Ontario (Table 2), with Canada Geese remaining in these areas from ca. 17 March to 4 April 2010 and from 10 to 30 April 2010. Canada Geese following this route also staged in the Ottawa River valley area of southeastern Ontario and southwestern Quebec before continuing north.

Females 6 and 7 completed the spring migration to the eastern shores of Hudson Bay around 9 June 2010. However, Female 6 took a lengthier migratory path, with a mean distance between stopover sites of 402 $\mathrm{km}$ and a total migration distance of $4020 \mathrm{~km}$, and Female 7 had a mean distance between stopover sites of $365 \mathrm{~km}$ and a total migration distance of $3650 \mathrm{~km}$ (Table 3). Female 7 made a direct flight from southern Quebec to the breeding grounds of the Atlantic Population on Hudson Bay, while Female 6 first flew to the south shore of Ungava Bay, then along the coast of Ungava Bay and across the Ungava Peninsula before settling on the east side of Hudson Bay.

Cropland was the most common habitat type within $10-\mathrm{km}$ buffers at stopover and staging sites utilized by Canada Geese (Table 4). Cropland comprised 35\% to $74 \%$ of the habitat at stopover sites in the United States and southern Canada. This habitat type decreased as a landscape component once Canada Geese migrated north of staging areas in the Ottawa River valley.

\section{Discussion}

Five of the eight Canada Geese fitted with satellite transmitters at Santee National Wildlife Refuge during the winter of 2009-2010 completed the spring migration to the breeding grounds of the Atlantic Population. Birds that were captured together did not all follow the same migration route to the breeding grounds. Females 1,3 , and 5 shared a common path (Route 1) that is typically associated with the breeding grounds of the Atlantic Population. However, Female 1 diverged from Females 3 and 5 north of southern Quebec. Females 6 and 7 shared a common path (Route 2) but diverged as they traveled through Quebec (Figure 1). Unlike Route 1, the portion of Route 2 that is within the USA is typically associated with birds destined for the breeding grounds of the Southern James Bay Population. The mechanisms underlying route choice in our study are unclear, but may be related to mate choice, shortterm weather patterns, or site fidelity.

The remaining three transmitters we deployed failed during migration. Banding returns demonstrated that two of these birds had been banded on the breeding grounds of the Atlantic Population in 2001 (Male 1) and 2003 (Female 2). Whether Male 1 and Female 2 were breeders from the Atlantic Population or resident Canada Geese from the Ottawa River valley that visited the breeding grounds of the Atlantic Population as moult-migrants and then wintered at Santee National Wildlife Refuge is not clear. None of the Canada Geese from our study were affiliated with the breeding grounds of the Southern James Bay Population. 
TABLE 4. Proportion of habitat classified as cropland within 10-km buffers of all stopover and staging sites used by spring migrant Canada Geese (Branta canadensis interior) captured at the Santee National Wildlife Refuge, South Carolina, in December 2009.

\begin{tabular}{lcl}
\hline \hline Stopover site & \% Cropland & Most common non-cropland land cover (\%) \\
\hline South Carolina & $34.8 \%$ & Water $(22.8 \%)$ \\
Northeastern North Carolina & $54.2 \%$ & Broadleaf deciduous forest $(27.3 \%)$ \\
Ohio & $74.4 \%$ & Temperate or subpolar broadleaf deciduous forest $(21.3 \%)$ \\
Western New York & $42.8 \%$ & Water $(31.7 \%)$ \\
Southwestern Ontario & $70.0 \%$ & Broadleaf deciduous forest $(10.3 \%)$ \\
Southeastern Ontario/southern Quebec & $36.3 \%$ & Temperate or subpolar broadleaf deciduous forest (33.2\%) \\
(along the Ottawa River) & & \\
Quebec south of $50^{\circ} 30^{\prime}$ north latitude & $9.0 \%$ & Temperate or subpolar broadleaf deciduous forest $(32.4 \%)$ \\
Ungava Bay & $0.0 \%$ & Subpolar or polar barren lichen $/$ moss $(39.0 \%)$ \\
Hudson Bay & $0.0 \%$ & Subpolar or polar grassland lichen $/$ moss $(76.8 \%)$ \\
\hline \hline
\end{tabular}

Canada Geese neck-collared on the breeding grounds of the Southern James Bay Population have previously been re-sighted wintering at Santee National Wildlife Refuge. For example, several Canada Geese $(<5)$ marked with neck collars on the breeding grounds of the Southern James Bay Population were observed among the approximately 500 migratory Canada Geese that wintered at Santee National Wildlife Refuge during the winter of 2008-2009 (M.G. personal observation).

After leaving the Santee National Wildlife Refuge, the Canada Geese fitted with satellite transmitters first traveled to either northeastern North Carolina or northeastern Ohio. Canada Geese captured on wintering grounds in the North Carolina coastal plain and in South Carolina at both the Santee National Wildlife Refuge and the Carolina Sandhills National Wildlife Refuge have used these same stopover areas (Malecki and Trost 1986; Fuller 2000*). Movements through the United States occurred relatively quickly, with Canada Geese remaining at stopovers for only 1-7 days. However, once the Canada Geese reached the Great Lakes and the Ottawa River valley areas of Canada, migratory movements slowed. Canada Geese that were neck-collared between 1983 and 1985 at the Pee Dee National Wildlife Refuge in North Carolina, at the Carolina Sandhills National Wildlife Refuge in South Carolina, and at the Santee National Wildlife Refuge also showed an affinity for southeastern Ontario during spring migration (Malecki and Trost 1986). Following lengthy staging events at stopovers $1.3,1.4,1.5$, 2.4 , and 2.5, Canada Geese fitted with satellite transmitters generally relocated north, making a few shorter flights in Quebec south of the breeding grounds of the Atlantic Population (stopovers 1.6, 1.7, 2.6, and 2.7). Although there were two separate migratory routes, the one similarity between Route 1 and Route 2 is the use of the stopover in southeastern Ontario and southern Quebec near the Ottawa River.

Satellite telemetry data reveal that the Canada Geese from our study shared migratory pathways with Canada Geese banded in the southeastern states and with Canada Geese marked with satellite transmitters on the breeding grounds of the Atlantic Population. In addition, we found similarities in migration chronology between our Canada Geese and those marked with satellite transmitters on the coast of Hudson Bay and Ungava Bay during the summers of 1996 and 1997 (Malecki et al. 2001). Although the birds tracked in 1996 and 1997 had a more widely distributed range of terminal wintering locations (including New Jersey, Maryland, Delaware, Virginia, Massachusetts, and Connecticut), the date of departure from the wintering grounds and dates of arrival at various stopovers in the United States and Canada were similar to those in this study (Malecki et al. 2001). For example, in spring of 1997, Canada Geese departed wintering locations by early March, then remained south of $47^{\circ}$ north latitude (the degree of latitude separating resident from migrant geese) during the month of April. Canada Geese then moved north of $47^{\circ}$ north latitude during May, arriving on breeding grounds between 25 May and 2 June 1997 (Malecki et al. 2001). This chronology nearly matches that of the Canada Geese satellitetagged in our study: they departed Santee National Wildlife Refuge by 5-7 March, remained south of $50^{\circ} 30^{\prime}$ north latitude until early May, and reached the breeding grounds of the Atlantic Population between 24 May and 9 June 2010.

In our study, agricultural fields were the dominant habitat type at stopover and staging sites in both the United States and southern Canada. Studies on habitat use and diet (Reed et al. 1977; Giroux and Bergeron 1996) have also shown that migratory Canada Geese and Greater Snow Geese (Chen caerulescens atlantica) in southern Canada frequent lands characterized by agricultural activities, and there appear to be few public lands in the area managed for waterfowl (J. Hughes, personal communication, 2010). The primary forage crop in southeastern Ontario and southwestern Quebec is corn, but soybean, wheat, oats, and barley are also available, as are dairy farms, which also provide foraging areas (Javorek et al. 2007). Canada Geese and Greater Snow Geese staging along the St. Lawrence River, which provides habitats similar to those utilized by the Canada Geese equipped with transmitters in our 
study, feed in cornfields, hayfields, and marshes, and they roost in flooded fields, rivers, and marshes (Bechet et al. 2003, 2004).

Birds likely remained on these cropland staging grounds obtaining nutrients used for breeding until weather conditions in the north permitted departure (Reed et al. 1977). The habitat at stopovers 1.7 and 2.6 are among the northernmost agricultural sites in Quebec. At stopovers 1.6 to 1.9 and 2.6 to 2.12, land cover is mostly dominated by forested habitats, with smaller percentages of grassland and wetland and a small amount of agricultural land. Therefore, the agricultural areas utilized during the lengthy staging period in southeastern Ontario and southern Quebec may provide critical staging areas for migratory geese from South Carolina and other southern states to gain body mass and nutrient reserves before departing for the breeding grounds (Alisauskas et al. 1988; Drent et al. 2007).

Canada Geese from both the Atlantic Population and the Southern James Bay Population are experiencing changes in their non-breeding habitats. For example, staging and wintering areas used by Canada Geese from the Atlantic Population support increasing numbers of Greater Snow Geese and resident Canada Geese, which may forage on agricultural food resources previously dominated by migratory Canada Geese (Davies and Hindman 2008*). Furthermore, the regions in which wintering and staging areas are found are also experiencing habitat loss and habitat conversion pressure from development (Brown et al. 2005).

Survey data demonstrate that the number of migratory Canada Geese wintering in the U.S. southeast has been declining for at least two decades, with causes attributed primarily to changes in farming and land use practices on staging and wintering grounds as well as to the lower survival of southern cohort Canada Geese and increasing populations of temperate-nesting Canada Geese (Abraham et al. 2008*; Davies and Hindman 2008*). Furthermore, in the Atlantic Flyway, Canada Geese from the Atlantic Population do not appear to be as strongly associated with public lands during the winter (Addy and Heyland 1968; Harvey 1987; Harvey et al. 1998). Providing habitat at key stopover, staging, and wintering locations will therefore require targeted conservation actions on both public and private lands. Federally funded and state-funded conservation programs (e.g., U.S. Farm Bill Programs) that provide financial incentives, privately funded conservation actions, and grant programs (e.g., U.S. North American Wetland Conservation Act) are tools that could be used to ensure that suitable stopover, staging, and overwintering habitat for migratory Canada Geese exist.

Despite what appears to be a strong reliance by Canada Geese on private lands as stopover habitat during our study, wintering and staging habitat for migratory geese are provided by state and federal public lands. Should private lands such as agricultural fields be developed, as is occurring adjacent to the Santee National Wildlife Refuge in South Carolina, geese that use those habitats may need to relocate. Identifying sites where habitat conversion or loss is likely to occur on or adjacent to private lands that currently serve as stopover, staging, or wintering areas throughout the Atlantic Flyway could help prioritize future conservation actions for migratory geese.

Our satellite telemetry data and the banding returns from two of the Canada Geese fitted with satellite transmitters demonstrated that geese from the breeding grounds of the Atlantic Population wintered at the Santee National Wildlife Refuge, which currently appears to represent the southernmost extent of the wintering range for this breeding population. Observational data from the Santee National Wildlife Refuge also demonstrated that Canada Geese from the Southern James Bay Population winter on the refuge. Our limited data do not allow the proportion of the southern-most wintering birds from each breeding population at the Santee National Wildlife Refuge to be estimated, and a study designed to further investigate breeding ground affiliations is warranted. Our results demonstrate that migratory Canada Geese wintering in southern states are associated with multiple breeding grounds and rely strongly on private agricultural lands for migratory habitat.

\section{Acknowledgements}

We thank the South Carolina Department of Natural Resources, Clemson University Department of Forestry and Natural Resources, the U.S. Geological Survey South Carolina Cooperative Fish and Wildlife Research Unit, the Santee National Wildlife Refuge (U.S. Fish and Wildlife Service), and the South Atlantic Migratory Bird Field Office of the U.S. Fish and Wildlife Service for funding and research support of this project. Haven Barnhill, Dean Harrigal, Buddy Baker, and the South Carolina Department of Natural Resources provided support during various phases of the project. We also thank the Florida Fish and Wildlife Conservation Commission, Delta Waterfowl, SC Ducks, the South Carolina Waterfowl Association, local hunters and landowners, and the many private contributors to this project. The manuscript benefited from reviews by Kevin Jacobs (Pennsylvania Game Commission) and two anonymous reviewers. The South Carolina Cooperative Fish and Wildlife Research Unit is supported by the South Carolina Department of Natural Resources, Clemson University, the U.S. Fish and Wildlife Service, and the U.S. Geological Survey. Any use of trade, product, or firm names is for descriptive purposes only and does not imply endorsement by the U.S. Government. This study was conducted under the auspices of the Clemson University Institutional Animal Use and Care Committee, permit AUP2009-003. 
Documents Cited (marked * in text)

Abraham, K. F., W. A. Phelps, and J. C. Davies. 2008. A management plan for the Southern James Bay Population of Canada geese. Mississippi and Atlantic Flyway Council Technical Sections. 56 pages.

Argos Inc. 2008. User's manual. Landover, Maryland. (http:// www.argos-system.org/manual).

Beyer, H. L. 2004. Hawth's Analysis Tools for ArcGIS. (http: //www.spatialecology.com/htools).

Davies, J. C., and L. Hindman. 2008. A management plan for the Atlantic population of Canada geese. Canada Goose Committee and Atlantic Flyway Technical Section. 52 pages.

Fuller, J. 2000. Movement and arrival dates of coastal plain, North Carolina winter banded Canada geese, 1984-1996. North Carolina Wildlife Resources Commission. 39 pages.

\section{Literature Cited}

Addy, C. E., and J. D. Heyland. 1968. Canada goose management in eastern Canada and the Atlantic flyway. Pages 10-23 in Canada Goose Management. Edited by R. L. Hine and C. Schoenfeld. Dembar Education Research Service, Madison, Wisconsin.

Alisauskas, R. T., C. D. Ankney, and E. E. Klaas. 1988. Winter diets and nutrition of midcontinental lesser snow geese. Journal of Wildlife Management 52: 403-414.

Bechet, A., J.-F. Giroux, G. Gauthier, J. D. Nichols, and J. E. Hines. 2003. Spring hunting changes the regional movements of migrating greater snow geese. Journal of Applied Ecology 40: 553-564.

Bechet, A., J.-F. Giroux, and G. Gauthier. 2004. The effects of disturbance on behaviour, habitat use and energy of spring staging snow geese. Journal of Applied Ecology 41: 689-700.

Bellrose, F. C. 1980. Ducks, geese and swans of North America. Third edition. Stackpole Books, Harrisburg, Pennsylvannia.

Brown, D. G., K. M. Johnson, T. R. Loveland, and D. M. Theobald. 2005. Rural land use trends in the conterminous United States, 1950-2000. Ecological Applications 15: $1851-1863$

Combs, D. L., K. L. Morgan, E. F. Bowers, and D. H. Orr. 2001. Migratory Canada goose population affiliation and interchange among four national wildlife refuges in Tennessee and Alabama. Pages 517-527 in Proceedings of the Fifty-fifth Annual Conference of the Southeastern Association of Fish and Wildlife Agencies, October 13-17, 2001, Louisville, Kentucky. Edited by Arnold G. Eversole, Kathi C. Wong, Michael Chamberlain, and John I. Galvez. Southeastern Association of Fish and Wildlife Agencies, Maggie Valley, North Carolina.

Commission for Environmental Cooperation. 2010. 2005 Land Cover of North America at 250 meters. Commission for Environmental Cooperation. (http://www.cec.org/atlas).

Drent, R. H., G. Eichhorn, A. Flagstad, A. J. Van der Graaf, K. E. Litvin, and J. Stahl. 2007. Migratory connectivity in arctic geese: spring stopovers are the weak links in meeting targets for breeding. Journal of Ornithology 148: S501-S514.

Giroux, J.-F., and R. Bergeron. 1996. Spring diets of sympatric greater snow geese and Canada geese in southern Quebec. Canadian Journal of Zoology 74: 950-953.

Harvey, W. F., IV. 1987. Winter movements and resource use by Canada geese affiliated with Kent County, Maryland. M.S. thesis, Cornell University, Ithaca, New York.
Harvey, W. F., IV, R. A. Malecki, and E. C. Soutiere. 1998. Roost site use and foraging flights by Canada geese wintering in Maryland. Pages 199-206 in Biology and Management of Canada Geese: Proceedings of the International Canada Goose Symposium. Edited by D. H. Rusch, M. D. Samuel, D. D. Humburg, and B. D. Sullivan. Proceedings of the International Canada Goose Symposium, Milwaukee, Wisconsin, April 23-23, 1998.

Haukos, D. A., M. R. Miller, D. L. Orthmeyer, J. Y. Takekawa, J. P. Fleskes, M. L. Casazza, W. M. Perry, and J. A. Moon. 2006. Spring migration of northern pintails from Texas and New Mexico, USA. Waterbirds 29: $127-136$.

Hindman, L. J., K. M. Dickson, W. F. Harvey IV, and J. R. Serie. 2004. Atlantic flyway Canada geese: new perspectives in goose management. Pages 12-21 in Proceedings of the International Canada Goose Symposium. Edited by T. J. Moser, R. D. Lien, K. C. Vercauteren, K. F. Abraham, D. E. Andersen, J. G. Bruggink, J. M. Coluccy, D. A. Graber, J. O. Leafloor, D. R. Luukkonen, and R. E. Trost. Proceedings of the International Canada Goose Symposium, Madison, Wisconsin, 19-21 March 2003.

Javorek, S. K., R. Antonowitsch, C. Callaghan, M. Grant, and T. Weins. 2007. Changes to wildlife habitat on agricultural lands in Canada, 1981-2001. Canadian Journal of Soil Science 87: 225-233.

Malecki, R. A., and R. E. Trost. 1986. Status and population affiliation of Canada geese wintering in North and South Carolina. Pages 446-453 in Proceedings of the Fortieth Annual Conference of the Southeastern Association of Fish and Wildlife Agencies, November 20-23, 1986, Baltimore, Maryland. Edited by Arnold G. Eversole, Kathi C. Sweeney, Loren Smith, Jeffrey W. Foltz, Sharon Cooper, and Dennis E. Hammond. Southeastern Association of Fish and Wildlife Agencies, Maggie Valley, North Carolina.

Malecki, R. A., B. D. J. Batt, and S. E. Sheaffer. 2001. Spatial and temporal distribution of Atlantic population Canada geese. Journal of Wildlife Management 65: 242247.

Miller, M. R., J. Y. Takekawa, J. P. Fleskes, D. L. Orthmeyer, M. L. Casazza, and W. M. Perry. 2005. Spring migration of northern pintails from California's central valley wintering area tracked with satellite telemetry: routes, timing, and destinations. Canadian Journal of Zoology 83: 1314-1332.

Orr, D. H., E. F. Bowers, and O. J. Florschutz, Jr. 1998. Canada geese population trends, distributions, and management strategies in the southeastern United States. Pages 239-248 in Proceedings of the International Canada Goose Symposium. Edited by D. H. Rusch, M. D. Samuel, D. D. Humburg, and B. D. Sullivan. Proceedings of the International Canada Goose Symposium, Milwaukee, Wisconsin, April 23-23, 1998.

Reed, A., G. Chapdelaine, and P. Dupuis. 1977. Use of farmland in spring by migrating Canada geese in the St. Lawrence valley, Quebec. Journal of Applied Ecology 14: 667-680.

U.S. Fish and Wildlife Service. 2008. Santee National Wildlife Refuge comprehensive conservation plan. U.S. Department of the Interior, Fish and Wildlife Service, Atlanta, Georgia. 216 pages.

Received 24 June 2012

Accepted 1 October 2012 